\title{
Productive parameters of growing lambs fed an extruded ration with different roughage: concentrate ratios
}

\section{Parâmetros produtivos de borregas em crescimento alimentadas com ração extrusada em diferentes relações volumoso: concentrado}

\author{
Karla Alves Oliveira ${ }^{1 *}$; Gilberto de Lima Macedo Júnior ${ }^{2}$; Carolina Moreira \\ Araújo $^{1}$; Marco Tulio Santos Siqueira ${ }^{3}$; Maria Júlia Pereira de Araújo ${ }^{3}$; \\ Thauane Ariel Valadares de Jesus ${ }^{3}$
}

\begin{abstract}
Feed consumption has a great influence on the growth and performance of animals since the intake of dry matter supplies the quantity of nutrients that are necessary to meet the maintenance and production requirements of these animals. The objective of this study was to evaluate the dry matter intake, body growth, weight gain and carcass characteristics (by ultrasonography) of lambs fed an extruded ration at different roughage $(\mathrm{R})$ : concentrate $(\mathrm{C})$ ratios. Thirty mixed race (Santa Inês x Dorper) lambs, aged 3 months and with an average weight of $20 \mathrm{~kg}$, were used. The treatments consisted of an extruded ration in 30R:70C and 70R:30C ratios, completely randomised to 2 treatments and 15 replicates. The means of the variables were evaluated using a Tukey test and a regression at the 5\% significance level. Dry matter intake (DMI), weight gain, body growth, evaluated through biometric measurements, and carcass characteristics, evaluated by ultrasonography, were assessed. There was a reduction of DMI in relation to body weight during the experimental period, with lower DMI amongst the animals in the 30R:70C treatment. There was a quadratic effect for the growth variables hindlimb height, forelimb height, body length, thoracic and barrel circumference over time, indicating that the animals presented adequate body growth, with intense development during the experimental period and stabilisation at the end of the experiment. There was no difference in the animals' weight gain, with an average daily gain of $182.79 \mathrm{~g} \mathrm{day}^{-1}$. There was a difference in carcass characteristics throughout the evaluation period, with a larger loin eye area, body condition score and subcutaneous fat thickness at the end of the experimental period. The use of an extruded ration with a 30\% roughage and $70 \%$ concentrate ratio promotes better feed efficiency in lambs, since it achieved the same weight gain and body development with lower dry matter intake.
\end{abstract}

Key words: Biometry. Extrusion. Nutrition. Ovis aries.

\section{Resumo}

O consumo de alimentos exerce grande influência no crescimento e desempenho dos animais visto que, será a partir da ingestão de matéria seca que ocorrerá o fornecimento da quantidade de nutrientes

1 Discentes, Curso de Doutorado, Programa de Pós-Graduação em Ciências Veterinárias, Universidade Federal de Uberlândia, UFU, Uberlândia, MG, Brasil. E-mail: karla.alves.oliveira@hotmail.com; carolina.am@hotmail.com

2 Prof. Dr., UFU, Faculdade de Medicina Veterinária, Programa de Pós-Graduação em Ciências Veterinárias, Uberlândia, MG, Brasil. E-mail: gilbertomacedojr@gmail.com

3 Discentes, Curso de Graduação em Zootecnia, UFU, Uberlândia, MG, Brasil. E-mail: marcotulio.s.siqueira@gmail.com; majuliapa@hotmail.com; ariel_valadares@hotmail.com

* Author for correspondence 
necessários para atender os requerimentos de mantença e de produção dos mesmos. Objetivou-se avaliar o consumo de matéria seca, crescimento corporal, ganho de peso e carcaça via ultrassonografia de cordeiros alimentados com ração extrusada em diferentes relações volumoso (V): concentrado (C). Foram utilizados 30 borregas, mestiças (Santa Inês x Dorper), com idade de três meses, e peso médio de $20 \mathrm{~kg}$. Os tratamentos consistiam de ração extrusada nas relações 30V:70C e 70V:30C, com os animais distribuídos inteiramente ao acaso com dois tratamentos e 15 repetições. As médias das variáveis analisadas foram avaliadas pelo teste de Tukey e estudo de regressão para as variáveis analisadas no período ao nível de significância de 5\%. Foram avaliados o consumo de matéria seca (CMS), ganho de peso, crescimento corporal através de medidas biométricas e avaliação de carcaça através de ultrassonografia. Houve redução do CMS em relação ao peso corporal ao longo do período experimental e menor CMS pelos animais no tratamento 30V:70C. Observou-se efeito quadrático para as variáveis de crescimento altura do posterior, altura do anterior, comprimento corporal, circunferência torácica e do barril, indicando que os animais apresentaram crescimento corporal adequado, com intenso desenvolvimento durante o período experimental e estabilização ao fim do experimento. Não observouse diferença no ganho de peso dos animais, sendo o ganho médio diário de $182,79 \mathrm{~g}$ dia-1. Com relação a avaliação de carcaça observou-se diferença no período de avaliação, com maior área de olho de lombo, escore de condição corporal e espessura de gordura subcutânea no final do período experimental. O uso da ração extrusada com relação $30 \%$ volumoso e $70 \%$ concentrado promove melhor conversão alimentar nos animais, uma vez que alcançou o mesmo ganho de peso e desenvolvimento corporal com menor consumo de matéria seca pelos animais.

Palavras-chave: Biometria. Extrusão. Nutrição. Ovis aries.

\section{Introduction}

Animal performance has a direct correlation with digestible dry matter intake. Food intake varies with the animal in terms of live weight and its variation, production level, physiological state and size. It also varies in terms of the food (fibre, volume, filling capacity, energy density and need to chew) and the feed conditions (food availability, trough space, feed access time, feeding frequency), in addition to the climatic conditions (GESUALDI JÚNIOR et al., 2000).

The main physical factors that control dry matter intake in high fibre diets are the passage rate and the filling capacity. In the case of high concentrate diets, the regulation of dry matter intake occurs through the energy demand and by metabolic factors (CONRAD et al., 1984; MERTENS, 1987; VAN SOEST, 1994). Usually, rations are composed of roughage and concentrate foods, so it is of great importance that the correct balance of these rations is made, which consequently determines the adequate roughage: concentrate ratio to meet the nutritional requirements of the animals. Both the feed balance and roughage: concentrate ratio will depend on the quality of the roughage and the concentrate feed used, the age and weight of the animals, as well as on the need for animal weight gain or milk production (CARDOSO, 1996), since higher rates of weight gain or milk production require a higher energy concentration feed.

Physical processes, such as the extrusion process, can be performed to improve the quality of the feed offered. Extrusion is a process of cooking at a high pressure, humidity and temperature over a short time. This process promotes an increase in the nutrient digestibility of the feed and, consequently, increases the weight and feed efficiency of the animals; in some cases, it significantly improves the palatability of the ingredients or rations (ROKEY et al., 2010; SILVA et al., 2015).

Among the tools used to measure the productivity of small ruminants, body biometry (as a way of assessing the growth of animals), which, when analysed along with other zootechnical indexes, constitutes an important database for the individual evaluation of animals and to determine the evolution of the productive system (SOUZA et al., 2014). In addition, these in vivo biometric measurements 
have a high correlation with carcass measurements and, together with other zootechnical indexes, can help to predict some productive characteristics, such as weight, carcass yield and conformation, the proportion of muscles and adipose tissue, as well as the yield of cuts, orienting producers to the best time to slaughter their animals (MORENO et al., 2010; PINHEIRO et al., 2007).

Ultrasonography is another tool that can be used in the evaluation of productivity, allowing for the analysis of carcass composition in a non-invasive way, leading to the quantification of different tissues in live animals. In the production of sheep meat, the carcass, along with its quantitative characteristics, is of fundamental importance since it is directly related to the final product. The ideal carcass is that with the highest proportion of muscle, minimum bone and an adequate amount of fat to meet the demands of consumers (OSÓRIO; OSÓRIO, 2005). Carcass composition can be estimated by measuring the loin eye area and the thickness of the subcutaneous fat taken at the place of the insertion of the $12^{\text {th }}$ and $13^{\text {th }}$ ribs, which present a high, positive correlation with the muscle distribution and the fat in the carcass, respectively (MCMANUS et al., 2013). Estimates obtained by ultrasonography have shown high repeatability and high correlations with the corresponding measurements taken from the carcass after slaughter (BELTRAME et al., 2011).

The objective of this study was to evaluate the dry matter intake, body growth, weight gain and carcass characteristics (by ultrasonography) of lambs fed an extruded ration in different roughage $(\mathrm{R})$ : concentrate $(\mathrm{C})$ ratios.

\section{Materials and Methods}

The experiment was carried out at the Federal University of Uberlândia (UFU), Capim Branco Experimental Farm, located in the city of Uberlândia, Minas Gerais. The experimental period was from December 17, 2016 to April 1 ${ }^{\text {st }}, 2017$. The experimental protocol was approved by the Ethics
Committee on the Use of Animals (ECUA) of UFU under number 140/16.

We used 30 half-blood lambs (Santa Inês and Dorper), with an initial mean weight of $20.7 \pm 4.7 \mathrm{~kg}$ and a mean age of 3 months old; they were weaned on September 28, 2016. All animals were weighed and dewormed with Levamisole and monepantel (oral) on the first day of the experiment, then placed in collective pens equipped with a feeder, drinker, salt shaker and slatted floor. Before the beginning of the experiment, the animals were fed a diet based on corn silage and bran concentrate (corn meal, soybean meal, urea and mineral salt).

The experiment lasted 105 days: the first 15 days were used to adapt the animals to the experimental conditions, and the remaining 90 days were used to collect data. The animals were divided into six groups of five animals; each group was housed in collective bays, with three bays for each evaluated treatment. These bays were each $20 \mathrm{~m}^{2}$ and were located in a covered masonry shed. The animals had ad libitum access to a drinking fountain with water and a bowl with mineral salt.

The feed was only composed of an extruded ration, with roughage and concentrate in the same pellet; the fibrous part of the feed was composed of forage of the genus Urochloa, and the concentrate part was composed of corn bran, soybean meal, starch, minerals and monensin. Then, the treatments were divided according to the roughage: concentrate ratio of the ration, either $70 \%$ roughage and $30 \%$ concentrate (70R: $30 \mathrm{C}$ ) or $30 \%$ roughage and 70\% concentrate (30R: 70C). The bromatological composition of the treatments is shown in Table 1. The commercial ration used was Beef Agnus ${ }^{\circledR}$ supplied by $\operatorname{Nutratta}^{\circledR}$ (undisclosed formula, industrial secret).

The ration was given twice per day (08:00h and 16:00h). The leftovers were measured daily and whenever the leftovers were equal to zero, the supplied quantity was increased, until reaching a surplus equivalent to $10 \%$ of the amount offered in 
the dry matter. The leftovers were weighed daily, allowing for the calculation of dry matter intake (DMI), using the formula: DMI $=$ (feed offered $\mathrm{x}$ $\%$ dry matter of the feed offered) - (leftovers $x \%$ dry matter of leftovers). As the feed offered and the leftovers were relative to the bay, to calculate the DMI of each animal, the DMI result was taken from the bay and divided by five (the number of animals per bay). DMI in relation to live weight was obtained through the relation between the DMI and the mean body weight of the animals throughout the evaluation period.

Table 1. Bromatological composition of the treatments.

\begin{tabular}{lcc}
\hline \multicolumn{1}{c}{ Nutrient } & $70 \mathrm{R}: 30 \mathrm{C}$ & $30 \mathrm{R}: 70 \mathrm{C}$ \\
\hline Dry matter (DM) & $92.07 \%$ & $92.05 \%$ \\
Crude protein (CP) & $10.82 \%$ & $13.64 \%$ \\
Neutral detergent fibre (NDF) $^{*}$ & $34.48 \%$ & $29.64 \%$ \\
Acid detergent fibre (ADF) $^{*}$ & $20.63 \%$ & $16.41 \%$ \\
Non-fibrous carbohydrate (NFC) & 49.57 \\
Ethereal extract (EE) & $47.60 \%$ & $2.21 \%$ \\
Mineral matter (MM) $^{* *}$ & $2.09 \%$ & $5.06 \%$ \\
Starch $^{* *}$ & $4.88 \%$ & $39.36 \%$ \\
Monensin $^{* *}$ & $33.84 \%$ & $39.76 \mathrm{mg} / \mathrm{kg}$ \\
\hline
\end{tabular}

* Values obtained after an analysis performed at the animal nutrition laboratory of the Animal Science course of the Federal University of Uberlândia, in partnership with the Federal Institute of the Triângulo Mineiro - Uberaba campus; ** Data provided by the manufacturer.

To evaluate performance, weight gain, body condition score (BCS), body growth and carcass characteristics were analysed. The evaluations were performed every 15 days, namely on the first day of the experiment (0), during the adaptation period, and later on days 15, 30, 45, 60, 75, 90 and 105, totaling eight evaluations. A carcass evaluation was performed at the beginning $(12 / 18 / 2016)$ and end $(03 / 25 / 2017)$ of the experiment, totaling two evaluations. All evaluations were performed in the morning before the first meal. On the same days as the ultrasound carcass evaluation, the BCS of the animals was also evaluated.

For in vivo carcass evaluation, an ultrasound was performed with a Mindray DP 2200 device. Each animal was restrained, with the tricotomy of the measurement area located between the $12^{\text {th }}$ and $13^{\text {th }}$ lumbar vertebrae. The fat thickness (FT) and height and length of the Longissimus dorsi muscle were obtained using an ultrasound, making it possible to calculate the loin eye area (LEA) using the formula proposed by Silva Sobrinho (1999):

$$
\mathrm{LEA}=(\mathrm{L} / 2 \times \mathrm{H} / 2) \times \pi
$$

Where: $\mathrm{L}=$ length of muscle; $\mathrm{H}=$ height of muscle; $\pi=3.1415926 \ldots$

To evaluate the animals' weight, a Wei Heng ${ }^{\circledR}$ digital scale with a precision of 10 grams was used. Weights were assessed on the same days as the biometric evaluations, always before the first meal was delivered.

BCS was always performed by the same trained evaluator (due to the subjectivity of the analysis) through the palpation of the $12^{\text {th }}$ and $13^{\text {th }}$ lumbar vertebrae, allowing for the evaluation of the deposition of fat in the animal. This was done using the scale proposed by Russel et al. (1969): 1 - very thin; 2 - lean; 3 - normal; 4 - fatty; 5 - obese. 
Biometric measurements were taken to evaluate the animals' body growth using a tape measure. For each measurement, the animal was kept calm and contained on a flat surface with all four feet resting on the floor and an aligned posture. The analysed variables were:

Forelimb height $(\mathrm{FH})$ : vertical distance between the highest point (in the direction of the scapula) and the ground;

Hindlimb height $(\mathrm{HH})$ : vertical distance between the highest point (in the direction of the ilium bone) and the ground;

Body length (BL): distance between the base of the tail (ischium bone) and the base of the neck (lateral aspect of the scapulohumeral joint);

Thoracic circumference (TC): measured in the posterior part of the shoulder blades near the armpits;

Chest width $(\mathrm{CW})$ : distance between the lateral sides of the right and left scapulo-umeral joints;

Barrel circumference (BC): circumference of the lower part to the ribs where the void is located.

A randomised design, with repeated measurements over time, 2 treatments and 15 replicates per treatment, was used. The means of the treatments were submitted to an analysis of variance and a Tukey's test at the 5\% significance level. For the evaluations of the time period, a regression study at the 5\% significance level was used, using the SAEG 9.0 program. For the evaluation of dry matter intake, the bays were used as a repetition, and thus, each treatment had three bays as a unit of repetition (each bay having five animals). The mean BCSs were evaluated by a Kruskal and Wallis (1952) non-parametric test. All variables were tested for the normality and homogeneity of the data.

\section{Results and Discussion}

The dry matter intake (DMI) in relation to body weight was higher for the lambs from the 70R: 30C treatment. For the intake (in kilograms) per animal, there was no difference between treatments (Table 2). The mean DMI per animal was $1.13 \mathrm{~kg}^{\mathrm{day}}{ }^{-1}$, which is within the recommended range for this animal category that is $1.0-1.3 \mathrm{~kg} \mathrm{day}^{-1}$ (NRC, 2007). The DMI in relation to body weight (DMI\% BW) recommended by the NRC (2007) is 3.51\%; that is, the animals who received the 30R: 70C treatment presented a DMI\% BW that was 3.4\% higher than the recommended level, whereas the animals fed 70R: 30C presented a DMI\% BW that was $13.9 \%$ higher than the recommendation.

The lowest intake amongst the animals consuming $70 \%$ concentrate may have been due to the metabolic regulation of intake, since the diet had high amounts of energy and protein in the rumen. Consequently, the amount ingested for maintenance and production may be higher than the nutritional requirement. Therefore, physiological mechanisms act to depress appetite and consequently reduce food consumption (OLIVEIRA et al., 2017).

During the evaluated period, there was a quadratic effect of the DMI per animal, with a higher intake during the second half of the experiment; for DMI\% BW, there was a negative linear effect, with lower DMI at the end of the experimental period. This response pattern may be due to the weight gain of the animals, since even if they were eating larger amounts of food at the end of the experiment, these animals were heavier, resulting in a reduction in DMI\% BW. Zanine and Macedo Júnior (2006) explained that a higher daily DMI is required to meet the nutritional requirements of growing animals. With higher intake, the fattening process begins; the animals become heavier, so when the relation between intake and body weight is calculated, this measure is reduced. Therefore, associated with this result, in relation to body weight, a difference was only observed over the evaluation period, with positive linear growth (Table 2); that is, there was a higher body weight of the animals at the end of the experimental period, contributing to the lower $\mathrm{DMI} \% \mathrm{BW}$, as was also found in this work. 
Table 2. Dry matter intake (DMI) per animal and in relation to body weight (DMI\% BW), and the weight of animals, according to the treatments and time period.

\begin{tabular}{cccc}
\hline Treatment & DMI/animal $\left(\mathrm{kg} \mathrm{day}^{-1}\right)$ & DMI\% BW $(\%)$ & Weight $(\mathrm{kg})$ \\
\hline 30R:70C & 1.08 & $3.63 \mathrm{~B}$ & 38.48 \\
70R:30C & 1.18 & $4.00 \mathrm{~A}$ & 30.15 \\
\hline Time period (days) & DMI/animal $^{1}\left(\mathrm{~kg} \mathrm{day}^{-1}\right)$ & DMI\% BW $^{2}(\%)$ & Weight $^{3}(\mathrm{~kg})$ \\
\hline 0 & - & - & 20.67 \\
15 & 0.94 & 4.27 & 23.42 \\
30 & 1.09 & 4.37 & 26.50 \\
45 & 1.21 & 4.04 & 29.04 \\
60 & 1.14 & 3.78 & 31.45 \\
75 & 1.19 & 3.62 & 34.50 \\
90 & 1.23 & 3.40 & 37.81 \\
105 & 1.24 & 3.20 & 39.70 \\
\hline Mean & 1.13 & 3.81 & 30.31 \\
CV & 6.48 & 5.88 & 6.95 \\
\hline
\end{tabular}

$\mathrm{CV}$ : coefficient of variation; ${ }^{1} \mathrm{Y}=0.872929+0.006769 \mathrm{x}-0.000031 \mathrm{x}^{2}, \mathrm{R}^{2}=94.91 \% ;{ }^{2} \mathrm{Y}=4.613843-0.013276 \mathrm{x}, \mathrm{R}^{2}=95.86 \% ;{ }^{3} \mathrm{Y}$ $=20.740227+0.183808 x, R^{2}=99.82 \%$.

There was no effect of treatment on mean daily weight gain (MDWG, Table 3). The MDWG for lambs throughout the experiment was 182.79 $\mathrm{g}$ (in the period from 0 to 105 days). This gain is very similar to that found by Carvalho et al. (2007), which was $171 \mathrm{~g}$, using feedlot lambs fed
Tifton-85 hay and ground concentrate in a 60R:40C ratio. However, for confined lambs fed a higher proportion of concentrate, gains of 350 to $450 \mathrm{~g}$ day $^{-}$ ${ }^{1}$ are expected (POLI et al., 2008; RIBEIRO et al., 2009). Animals consuming the 30R: $70 \mathrm{C}$ feed had a MDWG below the proposed level.

Table 3. Effect of different roughage: concentrate ratios of the extruded ration on the mean daily weight gain (MDWG, grams day ${ }^{-1}$ ) of crossbred lambs.

\begin{tabular}{|c|c|c|c|c|c|c|c|}
\hline \multirow{2}{*}{ Treatment } & \multicolumn{7}{|c|}{ Time period (days) } \\
\hline & $0-15$ & $15-30$ & $0-30$ & $30-45$ & $0-45$ & $45-60$ & $0-60$ \\
\hline 30R:70C & 197.51 & 216.68 & 207.10 & 173.75 & 195.88 & 162.28 & 181.63 \\
\hline 70R:30C & 168.97 & 194.91 & 181.94 & 179.24 & 176.06 & 206.28 & 185.64 \\
\hline Mean & 183.24 & 205.80 & 194.52 & 176.49 & 186.02 & 184.28 & 183.63 \\
\hline $\mathrm{CV}$ & 36.30 & 29.02 & 23.60 & 36.81 & 21.91 & 34.04 & 19.00 \\
\hline \multirow{2}{*}{ Treatment } & \multicolumn{6}{|c|}{ Time period (days) } & \\
\hline & $60-75$ & $0-75$ & $75-90$ & $0-90$ & $90-105$ & $0-105$ & \\
\hline 30R:70C & 235.31 & 186.04 & 211.75 & 193.28 & 155.57 & 183.54 & \\
\hline 70R:30C & 195.04 & 182.69 & 194.05 & 183.54 & 190.79 & 182.03 & \\
\hline Mean & 215.17 & 184.37 & 202.90 & 188.41 & 173.18 & 182.79 & \\
\hline $\mathrm{CV}$ & 32.29 & 18.16 & 28.97 & 24.29 & 33.31 & 17.83 & \\
\hline
\end{tabular}

$\mathrm{CV}$ : coefficient of variation. 
There was no effect of the use of different roughage: concentrate ratios on the following biometric measurements $(\mathrm{P}<0.05)$ : forelimb height (FH), hindlimb height $(\mathrm{HH})$, thoracic circumference (TC), barrel circumference (CB), body length (BL) and body condition score (BCS, Table 4). Therefore, the two treatments were effective in promoting the adequate body development of the animals. This was also observed by Moreno et al. (2010), who worked with growing lambs (initial weight of $15 \mathrm{~kg}$ ), using two roughage: concentrate ratios (60R: 40C and 40R: 60C), with the roughage being corn or cane silage sugarcane, and the ground concentrate based on corn and soybean meal. They evaluated the biometric measurements $\mathrm{FH}, \mathrm{HH}, \mathrm{TC}$ and $\mathrm{BL}$, finding values of $57.50,58.45,76.35$ and $56.80 \mathrm{~cm}$, respectively, for the treatment with the lower concentrate content and 57.35, 58.65, 77.15 and $56.00 \mathrm{~cm}$, respectively, for the treatment with the higher concentrate content.

Table 4. Effect of different roughage: concentrate ratios of the extruded ration and the time period on the biometric measurements and body condition scores of crossbred lambs.

\begin{tabular}{ccccccc}
\hline Treatment & $\mathrm{FH}(\mathrm{cm})$ & $\mathrm{HH}(\mathrm{cm})$ & $\mathrm{TC}(\mathrm{cm})$ & $\mathrm{BC}(\mathrm{cm})$ & $\mathrm{BL}(\mathrm{cm})$ & $\mathrm{BCS}$ \\
\hline 30R:70C & 54.80 & 56.20 & 71.79 & 82.28 & 63.61 & 3.19 \\
70R:30C & 55.06 & 56.52 & 71.73 & 82.66 & 62.99 & 3.12 \\
\hline Time period (days) & $\mathrm{FH}^{1}(\mathrm{~cm})$ & $\mathrm{HH}^{2}(\mathrm{~cm})$ & $\mathrm{TC}^{3}(\mathrm{~cm})$ & $\mathrm{BC}^{4}(\mathrm{~cm})$ & $\mathrm{BL}^{5}(\mathrm{~cm})$ & $\mathrm{BCS}^{*}$ \\
\hline 0 & 48.60 & 50.23 & 59.96 & 67.40 & 55.33 & $2.81 \mathrm{~B}$ \\
15 & 52.33 & 53.43 & 63.26 & 72.83 & 57.53 & $2.81 \mathrm{~B}$ \\
30 & 53.63 & 55.13 & 66.80 & 77.80 & 59.96 & $2.76 \mathrm{~B}$ \\
45 & 54.56 & 55.83 & 72.03 & 83.70 & 63.10 & $2.88 \mathrm{~B}$ \\
60 & 55.76 & 57.13 & 74.90 & 86.00 & 65.23 & $3.00 \mathrm{~B}$ \\
75 & 56.90 & 58.53 & 76.77 & 87.93 & 66.36 & $3.33 \mathrm{AB}$ \\
90 & 58.55 & 60.00 & 79.68 & 90.51 & 69.06 & $3.81 \mathrm{~A}$ \\
105 & 59.41 & 60.89 & 81.27 & 94.06 & 70.20 & $3.87 \mathrm{~A}$ \\
\hline Mean & 54.93 & 56.36 & 71.76 & 82.44 & 63.29 & 3.15 \\
$\mathrm{CV}$ & 4.59 & 4.55 & 4.79 & 4.97 & 4.47 & 11.03 \\
\hline
\end{tabular}

*Non-parametric statistics; FH: forelimb height; HH: hindlimb height; TC: thoracic circumference; BC: barrel circumference; BL: body length; BCS: body condition score; $\mathrm{CV}$ : coefficient of variation. ${ }^{1} \mathrm{Y}=49.384291+0.138719 \mathrm{x}-0.000431 \mathrm{x}^{2}, \mathrm{R}^{2}=97.39 \% ;{ }^{2} \mathrm{Y}$ $=50.838458+0.134678 \mathrm{x}-0.000383 \mathrm{x}^{2}, \mathrm{R}^{2}=98.26 \% ;{ }^{3} \mathrm{Y}=54.430747+0.303207 \mathrm{x}-0.000892 \mathrm{x}^{2}, \mathrm{R}^{2}=99.43 \% ;{ }^{4} \mathrm{Y}=67.537069+$ $0.388917 \mathrm{x}-0.001377 \mathrm{x}^{2}, \mathrm{R}^{2}=99.18 \% ;{ }^{5} \mathrm{Y}=55.084100+0.187791 \mathrm{x}-0.000404 \mathrm{x}^{2}, \mathrm{R}^{2}=99.52 \%$.

Sheep present a sigmoid growth curve. After birth, during the initial phase, these animals show slow growth, which increases rapidly, soon afterwards accelerating to puberty; after puberty, when growth reaches more advanced stages, the growth rate is reduced, canceling out at maturity (SILVA, 2017). The animals in both treatments showed constant growth, as expected, since they were close to puberty at the end of the experiment.

There was a quadratic effect of the time period on the biometric measurements $\mathrm{FH}, \mathrm{HH}, \mathrm{TC}, \mathrm{BC}$ and
BL, which shows that the animals at the end of the experiment were reaching sexual maturity (close to 6-7 months), displaying slowed growth. At the end of the experiment, there was a decrease in DMI\% $\mathrm{BW}$, concomitant to the stabilisation of the animals, indicating that the animals reached the optimal intake to meet their nutritional requirements, and were also heavier. Barrel circumference is directly related to the dry matter intake (DMI) of the animals, since the greater the barrel circumference, the greater the ingestive capacity of the animal. 
Therefore, when there was a stabilisation of the growth of this measure, there was a reduction with a tendency for the stabilisation of the DMI (Table 2). From 90 days, there were higher BCS values, since these animals had stabilised muscle growth, and the deposition of fat in the carcass had begun.

There was an interaction between treatment and time period for the biometric chest width $(\mathrm{CW})$ measurement, in which there was a linear increase of $\mathrm{CW}$ throughout the experimental period for the two studied roughage: concentrate ratios (Table 5).
According to Marques et al. (2008), CW is one of the biometric measures that can be used to predict live weight at slaughter in Santa Inês animals. However, Souza et al. (2014) showed that despite the high correlation of $\mathrm{CW}$ with the live weight of lambs, it is less predictive of the body weight of these animals. However, in this study, the body weight (Table 2) of the animals and the increase in chest width showed a positive linear growth; that is, as the chest width increased, there was an increase in body weight.

Table 5. Chest width $(\mathrm{cm})$ with respect to the interaction between roughage: concentrate ratios and time period.

\begin{tabular}{lcccccccc}
\hline \multirow{2}{*}{ Treatment } & \multicolumn{7}{c}{ Time period (days) } \\
\cline { 2 - 9 } & 0 & 15 & 30 & 45 & 60 & 75 & 90 & 105 \\
\hline 30R:70C & 16.46 & 17.53 & 18.93 & 20.00 & 21.20 & 20.06 & 23.53 & 24.53 \\
70R:30C & 15.93 & 17.20 & 17.86 & 19.46 & 20.26 & 22.33 & 24.07 & 24.35 \\
\hline Mean & \multicolumn{7}{c}{20.20} \\
CV & \multicolumn{7}{c}{8.95} \\
\hline
\end{tabular}

CV: coefficient of variation; ${ }^{1} \mathrm{Y}=16.488889+0.072275 \mathrm{x}, \mathrm{R}^{2}=92.19 \% ;{ }^{2} \mathrm{Y}=15.706746+0.085336 \mathrm{x}, \mathrm{R}^{2}=98.30 \%$.

According to the literature (CARVALHO et al., 2007; MURTA et al., 2009), the ideal slaughter weight of lambs is between 30 and $35 \mathrm{~kg}$, since it is when the proportion of muscles in the carcass is maximised and there is enough fat to provide the meat with sensory properties appropriate for consumer market preferences. In view of this, the animals in this study could be slaughtered between days 60 and 75 of the experiment, which is equivalent to the period in which the animals were approximately 5-6 months old; that is, from this period, the animals had stabilising muscle growth, and initiating fat accumulation in the carcass, which is evident from the higher BCS observed at the end of the experimental period (Table 4).

Relating the results found in this work, both the decrease in $\mathrm{DMI} \% \mathrm{BW}$, the stabilisation in body growth and the higher BCS at the end of the experimental period can be explained by the anticipation of puberty. Several factors influence the onset of puberty in sheep, and nutrition is cited as one of them. Monteiro et al. (2010) report that the sexual development of sheep is more related to body development than to chronological age, and when there is an improvement in the quality of the food provided, puberty is reached early. As such, it is possible that the animals used in this study reached puberty early.

There was no effect of the different roughage: concentrate ratios on the evaluated carcass characteristics (Table 6). In relation to the evaluation period, there was an increase in BCS, fat thickness (FT), loin eye area (LEA) and Longissimus dorsi muscle length at 90 days of the experiment. At the end of the experiment, BCS and FT were $35.5 \%$ and $63.8 \%$, respectively, higher than at the beginning of the experiment. As previously mentioned, the large BCS and FT can be attributed to puberty, since the 
animals began depositing fat at the expense ofmuscle deposition. According to Luchiari Filho (2000), the LEA measurement is also used as an indicator of the carcass composition, with a positive correlation between the LEA and the consumable portion of the carcass; as LEA increases, the consumable portion of the carcass increases, and vice versa.

Table 6. Effect of different roughage: concentrate ratios of the extruded ration on the in vivo carcass characteristics of crossbred lambs.

\begin{tabular}{cccccc}
\hline Treatment & BCS & FT $(\mathrm{mm})$ & LEA $\left(\mathrm{cm}^{2}\right)$ & Height $(\mathrm{cm})$ & Length $(\mathrm{cm})$ \\
\hline 30R:70C & 3.34 & 1.75 & 8.10 & 2.78 & 3.83 \\
70R:30C & 3.26 & 1.66 & 7.91 & 2.68 & 3.90 \\
\hline Time period (days) & BCS* & FT $(\mathrm{mm})$ & LEA $\left(\mathrm{cm}^{2}\right)$ & Heigt $(\mathrm{cm})$ & Length $(\mathrm{cm})$ \\
\hline 0 & $2.81 \mathrm{~B}$ & $1.30 \mathrm{~B}$ & $6.68 \mathrm{~B}$ & 2.76 & $3.33 \mathrm{~B}$ \\
90 & $3.81 \mathrm{~A}$ & $2.13 \mathrm{~A}$ & $9.37 \mathrm{~A}$ & 2.69 & $4.42 \mathrm{~A}$ \\
\hline Mean & 3.30 & 1.71 & 8.00 & 2.73 & 3.87 \\
CV & 6.48 & 19.59 & 8.41 & 10.22 & 4.85 \\
\hline
\end{tabular}

*Non-parametric statistics; BCS: body condition score; FT: fat thickness; LEA: loin eye area; CV: coefficient of variation. Different letters within a column differ by a Tukey's test at $5 \%$.

At the end of the experiment, the LEA was approximately $29 \%$ larger than at the start of the experiment. Cartaxo et al. (2011) showed that the higher the concentration of energy in the diet, the greater the LEA and, consequently, the greater the amount of muscle on the carcass. It is also worth mentioning that this measure was correlated with the other variables analysed in this study; that is, at the end of the experiment period, we also observed an increase in the biometric measurements, BCS and FT, contributing to a higher LEA.

The longer length of the Longissimus dorsi muscle observed at 90 days was related to the growth response of these animals (Table 4), since they presented uniform growth for the measures of length (body length) and height (forelimb height and hindlimb height).

\section{Conclusion}

The use of an extruded ration with a 30\% roughage and $70 \%$ concentrate ratio promotes better feed conversion in lambs, since this diet led to the same weight gain and body development with lower dry matter consumption. However, extruded feed with $70 \%$ roughage and 30\% concentrate can be economically more viable, because it leads to similar performance and lower cost due to the greater proportion of roughage.

\section{References}

BELTRAME, R. T.; FERNANDES, D. R.; QUIRINO, C. R. Utilização do ultras-som em tempo real na avaliação da carcaça de pequenos ruminantes. Publicações em Medicina Veterinária e Zootecnia, Londrina, v. 5, n. 3, p. 1-13, 2011.

CARDOSO, G. E. Engorda de bovinos em confinamento. Campo Grande: EMBRAPA Gado de Corte, 1996. 36 p.

CARTAXO, F. Q.; SOUSA, W. H.; COSTA, R. G.; CEZAR, M. F.; PEREIRA FILHO, J. M.; CUNHA, M. G. G. Características quantitativas da carcaça de cordeiros de diferentes genótipos submetidos a duas dietas. Revista Brasileira de Zootecnia, Piracicaba, v. 40, n. 10, p. 22202227, 2011. DOI: 10.1590/S1516-35982011001000023

CARVALHO, S.; BROCHIER, M. A.; PIVATO, J.; TEIXEIRA, R. C.; KIELING, R. Ganho de peso, características da carcaça e componentes não-carcaça de cordeiros da raça Texel terminados em diferentes 
sistemas alimentares. Ciência Rural, v.37, n.3, p.821827, 2007. DOI: $10.1590 /$ S0103-84782007000300034

CONRAD, H. R.; WEISS, W. P.; ODWONGO, W. O.; SHOCKEY, W. L. Estimating net energy lactation from components of cell solubles and cell walls. Journal of Dairy Science, Champaign, v. 67, n. 2, p. 427-436, 1984. DOI: $10.3168 /$ jds.S0022-0302(84)81320-X

GESUALDI JÚNIOR, A.; PAULINO, M. F.; VALADARES FILHOS, S. C.; SILVA, J. F. C.; VELOSO, C. M.; CECON, P. R. Níveis de concentrado na dieta de novilhos F1 Limousin x Nelore: consumo, conversão alimentar e ganho de peso. Revista Brasileira de Zootecnia, Piracicaba, v. 29, n. 5, p. 1458-1466, 2000. DOI: 10.1590/S1516-35982000000500026

KRUSKAL, W. H.; WALLIS, W. A. Use of ranks in onecriterion variance analysis. Journal American Statistical Association, New York, v. 47, n. 260, p. 583-621, 1952. DOI: $10.1080 / 01621459.1952 .10483441$

LUCHIARI FILHO, A. Pecuária da carne bovina. São Paulo: A. Luchiari Filho, 2000. 134 p.

MARQUES, A. V. S. M.; COSTA, R. G.; SILVA, A. M. A.; PEREIRA FILHO, J. M.; LIRA FILHO, G. E.; SANTOS, N. M. Feno de flor de seda (Calotropis procera $\mathrm{SW}$ ) em dietas de cordeiros Santa Inês: biometria e rendimento dos componentes não-constituintes da carcaça. Revista Brasileira de Ciências Agrárias, Recife, v. 3, n. 1, p. 8589, 2008. DOI: 10.5039/agraria.v3i1a296

MCMANUS, C.; PAIM, T. P.; LOUVANDINI, H.; DALLAGO, B. S. L.; DIAS, L. T.; TEIXEIRA, R. A. Avaliação ultrassonográfica da qualidade de carcaça de ovinos Santa Inês. Ciência Animal Brasileira, Goiânia, v. 14 , n. 1 , p. $8-16$, 2013. DOI: 10.5216/cab.v14i1.12336

MERTENS, D. R. Predicting intake and digestibility using mathematical models of ruminal function. Journal of Dairy Science, Champaign, v. 64, n. 5, p. 1548-1558, 1987. DOI: $10.2527 /$ jas $1987.6451548 x$

MONTEIRO, C. D.; BICUDO, S. D.; TOMA, H. S. Puberdade em fêmeas ovinas. Publicações em Medicina Veterinária e Zootecnia, Londrina, v. 4, n. 21, art. 856, p. 1-19, 2010.

MORENO, G. M. B.; SILVA SOBRINHO, A. G.; LEÃO, A. G.; OLIVEIRA, R. V.; YOKOO, M. J. I.; SOUSA JÚNIOR, S. C.; PEREZ, H. L. Características morfológicas in vivo e da carcaça de cordeiros terminados em confinamento e suas correlações. Revista Brasileira de Saúde e Produção Animal, Salvador, v. 11, n. 3, p. 888-902, 2010.

MURTA, R. M.; CHAVES, M. A.; SILVA, F. V.; BUTERI, C. B.; FERNANDES, O. W. B.; SANTOS, L. X. Ganho em peso e características da carcaça de ovinos confinados alimentados com bagaço de cana hidrolisado com óxido de cálcio. Ciência Animal Brasileira, Goiânia, v. 10, n. 2, p. 438-445, 2009.

NACIONAL RESEARCH COUNCIL - NRC. Nutrient requirements of small ruminants: sheep, goats, cervids, and new world camelids. Washington: National Academy Press, 2007. 384 p.

OLIVEIRA, B. C.; CAETANO, G. A. O.; CAETANO JÚNIOR, M. B.; MARTINS, T. R.; OLIVEIRA, C. B. Mecanismos reguladores de consumo em bovinos de corte: Fatores físicos, fatores químicos, fatores psicogênicos, ingestão de água. Revista Eletrônica Nutritime, Viçosa, MG, v. 14, n. 4, p. 6066-6075, 2017.

OSÓRIO, J. C. S.; OSÓRIO, M. T. M. Produção de carne ovina: técnicas de avaliação in vivo e na carcaça. 2. ed. Pelotas: Universidade Federal de Pelotas, 2005. 82 p.

PINHEIRO, R. S. B.; SILVA SOBRINHO, A. G.; MARQUES, C. A. T.; YAMAMOTO, S. M. Biometria in vivo e da carcaça de cordeiros confinados. Archivos de Zootecnia, Córdoba, v. 56, n. 216, p. 955-958, 2007.

POLI, C.H. E. C.; MONTEIRO,A. L. G.; BARROS, C. S.; MORAES, A.; FERNANDES, M. A. M.; PIAZZETTA, H. L. Produção de ovinos de corte em quatro sistemas de produção. Revista Brasileira de Zootecnia, Piracicaba, v. 37, n. 4, p. 666- 673, 2008. DOI: 10.1590/S151635982008000400012

RIBEIRO, T. M. D.; MONTEIRO, A. L. G.; PRADO, O. R.; NATEL, A. S.; SALGADO, J. A.; PIAZZETTA, H. L.; FERNANDES, S. R. Desempenho e características das carcaças de cordeiros em quatro sistemas de produção. Revista Brasileira de Saúde e Produção Animal, Salvador, v. 10, n. 2, p. 366-378, 2009.

ROKEY, G. J.; PLATTNER, B.; SOUZA, E. M. Feed extrusion process description. Revista Brasileira de Zootecnia, Viçosa, MG, v. 39, p. 510-518, 2010. Suplement Special. DOI: 10.1590/S1516-35982010001300055

RUSSEL, A. J. F.; DONEY, J. M.; GUNN, R. G. Subjective assessment of body fat in live sheep. Journal Agricultural Science, Toronto, v. 72, n. 3, p. 451-454, 1969. DOI: $10.1017 / \mathrm{S} 0021859600024874$

SILVA SOBRINHO, A. G. Body composition and characteristics of carcass from lambs of different genotypes and ages at slaughter. 1999. Report (Post Doctorate in Sheep Meat Production) - Massey University, Palmerston North.

SILVA, M. F. L.; SANTOS, L.; CHOUPINA, A. A extrusão em tecnologia alimentar: tipos, vantagens e equipamentos. Revista de Ciências Agrárias, Lisboa, v. 38, n. 1, p. 3-10, 2015. DOI: $10.19084 /$ rca. 16862 
SILVA, S. N. Crescimento e desenvolvimento de ovinos da raça Santa Inês. 2017. Dissertação (Mestrado em Zootecnia) - Universidade Estadual do Sudoeste da Bahia, Itapetinga.

SOUZA, D. S.; SILVA, H. P.; CARVALHO, J. M. P.; MELO, W. O.; MONTEIRO, B. M.; OLIVEIRA, D. R. Desenvolvimento corporal e relação entre biometria e peso de cordeiros lactantes da raça Santa Inês criados na Amazônia. Arquivo Brasileiro de Medicina Veterinária e Zootecnia, Belo Horizonte, v. 66, n. 6, p. 1787-1794, 2014. DOI: $10.1590 / 1678-7364$

VAN SOEST, P. J. Nutritional ecology of the ruminant. $2^{\text {th }}$ ed. Ithaca: Cornell University Press, 1994. 476 p.

ZANINE, A.; MACEDO JÚNIOR, G. L. Importância do consumo da fibra para nutrição de ruminantes. Revista Eletrônica de Veterinária, Andalucia, v. 7, n. 2, p. 1-11, 2006. 
